\title{
道路狭さくの設置効果と交通安全対策に対する 住民意識の変化に関する分析
}

\author{
鈴木 弘司 1 ・伊藤 大貴 2 \\ 1 正会員 名古屋工業大学大学院准教授 工学研究科（干466-8555 名古屋市昭和区御器所町） \\ E-mail: suzuki.koji@nitech.ac.jp \\ 2 正会員 株式会社長大 都市マネジメント事業部（†450-0003 名古屋市中村区名駅南 1-18-24） \\ E-mail: itou-hr@chodai.co.jp
}

\begin{abstract}
本研究では, 名古屋市天白区植田東学区を対象として, 生活道路の交通課題を観測調查, アンケートに より明らかにし，それらを踏まえて企画した単独狭さく設置の社会実験ならびにその後整備された連続狭 さくに関して，狭さく設置による交通流動の変化を分析した，その結果，狭さく設置区間では，単独，連 続狭さくともに自動車速度が低下寸ることが示された．また，地域住民の生活道路安全対策や道路狭さく 設置に対する意識の変化を把握するため, 対策効果や支払意思額に関するアンケートを 3 時点で実施した. その結果, 狭さく設置前では子どもの有無や狭さく区間利用の有無が支払意思へ影響していたが，狭さく 設置経過後では，同区間の利便性や道路狭さく効果の実感の有無が影響するなど，施策に対する意識の変 化が確認された。
\end{abstract}

Key Words : residential road, traffic safety, choker, CVM

\section{1. はじめに}

日本の交通事故死亡者数は，いわゆる「交通戦争」と 呼ばれる時代の 1970 年（昭和 45 年）に過去最多を記録 し，1992年（平成 4 年）に二度目のピークをむかえて以 降, 年々減少傾向にある ${ }^{1)}$. しかし, 状態別死者数では, 歩行中の死亡者数が自動車乗車中の死者数を抜き，2008 年 (平成 20 年) 以降最多となっている ${ }^{2}$. また, 自宅か らの距離別死亡事故発生状況では，6割が自宅から $500 \mathrm{~m}$ 以内の身近な道路で発生している ${ }^{3)}$ ．さらに，危険察知 能力が成人よりも低く, 通学手段が徒歩であり, 生活圈 が自宅周辺に限られやすい子どもの歩行中事故について は 5 割が，自宅から $500 \mathrm{~m}$ 以内で発生していることが分 かっている4

自動車の速度は, 全ての交通事故を悪化させる要因で ある. 自動車の平均速度が 5\%低下寸ることで，人身事 故は 10\%減少し，死亡事故は 20\%も減少するといわれて おり 5), 速度と致死率の関係は，30km/ を境に急激に増 大寸ることも示されている の.このような背景からわが 国では近年, $30 \mathrm{~km} / \mathrm{h}$ の速度規制を面的に行う施策（ゾー ン 30）が推進されており，本施策により交通事故減少 効果が発現することが確認されている》。.

他方，幹線道路の交差点を中心に慢性的に発生してい
る交通渋滞を回避するため非幹線道路に流入してくる通 過交通は，生活道路の交通量を増大させ，居住環境や安 全環境を悪化させる要因となるうえ，高速で通過するた め, 生活道路での交通事故を発生させている可能性が考 えられる. そのため, 生活道路においては, 自動車の速 度抑制や通過交通対策を実施することで，地域の交通環 境を改善し, 歩行者の通行環境を守り, 地域住民が暮ら しやすい道路環境を作ることが必要であるといえる。

車両速度抑制の物理的デバイスに関する既往研究とし

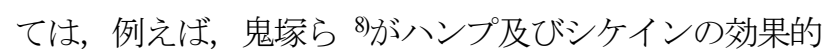
な設置位置と間隔に関する研究を，大橋ら ${ }^{9}$ がスムース 歩道及び交差点道路狭さくの効果に関する研究を行って いる. また，伊藤ら ${ }^{10} /$ は道路狭さく設置による速度抑制 効果や騷音一の影響に関する研究を行っている. 国土交 通省は 2015 年度, 生活道路における物理的デバイス等 検討委員会を設置し，物理的デバイスの計画・設計に関 する基準案を示している ${ }^{11)}$. しかしながら，物理的デバ イスの設置検討に関して，地域住民が望む交通安全施策 とデバイスの設置効果に関して多面的に実証分析した例 は少ないといえる.

このような状況の下, 名古屋市天白区植田東学区では, 地域と大学により共同実施された住民へのアンケートや 交通実態調査結果を踏まえて, 地域住民, 道路管理者, 
交通管理者との連携協力のもと，主として車両の速度抑 制と横断者の安全性向上を目的とした，単独の道路狭さ くによる社会実験が実施された，さらに，その結果を踏 まえて同地域内で連続の道路狭さく整備が進められた。

本研究では, 社会実験の実施前, 実施中, 実験後およ び連続狭さく整備後において観測調査およびアンケート 調査を行い，観測調査で取得される車両挙動の変化や住 民へのアンケート結果から得られる対策による円滑性, 安全性の変化から生活道路における道路狭さくの設置効 果を分析する.

また，交通安全事業に対する効果について，車両挙動 や住民意識に加えて, 物理的デバイスの設置普及の費用 対効果の試算や設置普及効果（住民の理解度）を定量的 に評価するため，仮想市場評価法を導入し，生活道路安 全対策や道路狭さくへの経済的価值の評価などを経時的 に評価する.

\section{2. 対象地域概要}

本研究では，愛知県名古屋市天白区の植田東学区を分 析対象とする. 本対象地区は, 名古屋市東端に位置し日 進市に隣接しており, 図-1に示すように名古屋第二環状 自動車道（名二環）植田 ICおよび，一般国道302号線と 一般国道 153 号線の交差する大規模交差点や, 主要地方 道県道名古屋岡崎線（飯田街道）がある. また, 地理的 に名古屋市中心部と郊外地域を結ぶ位置にあるため, 特 に朝夕の通勤通学時間帯の交通量が多い地区となってい る. そのため, 周辺の幹線道路の啮滞や信号待ち回避の ため本地区内に流入する通過交通による居住環境や交通 安全環境が悪化し, 通学中の小学生が危険な状況にさら されていることが懸念される.

2012 年 11 月に植田東学区連絡協議会交通部会（以下, 交通部会）により実施された，植田東学区全体に関する 住民アンケート調查では，挙げられた学区の課題の5 割 以上が交通安全に関寸るものであること，また，学区南 側に位置し, 名古屋市立植田東小学校につながる東西道 路（以下，高架下道路）は，小学校の通学路に指定され ているにも関わらず，交通量が多く横断ポイントが少な い等多くの課題が存在していることが確認された.

\section{3. 分析対象地区の事前の交通特性と交通課題}

2012 年 11 月の調査で明らかとなった高架下道路の交 通課題を踏まえ，2014年度交通実態調査として，地区内 における自動車 OD や交通挙動を取得するため, 植田東 学区内の主要交差点計 8 箇所（図-1）にてナンバープレ

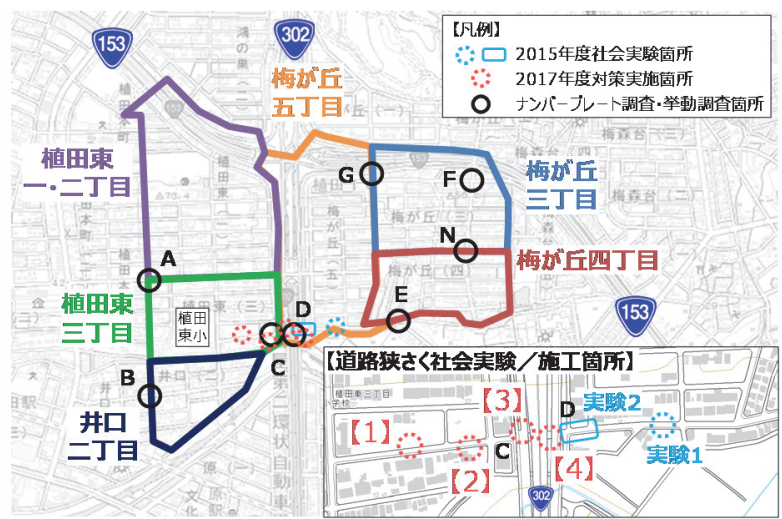

図-1 ナンバープレート調查・挙動調査・道路狭さく設置箇所 表-1 交通実態調査概要 (2014年度)

\begin{tabular}{|c|c|c|c|c|c|}
\hline & \multicolumn{3}{|c|}{ 交通挙動調査 } & \multicolumn{2}{|c|}{ ナンバープレート調査 } \\
\hline \multirow{3}{*}{ 日時 } & \multicolumn{5}{|c|}{ 2014年7月8日 (火) } \\
\hline & 朝 & 夕 & 夕 & 朝 & 夕 \\
\hline & $7: 30 \sim 9: 00$ & $15: 00 \sim 18: 00$ & $16: 30 \sim 18: 00$ & $7: 30 \sim 9: 00$ & $16: 30 \sim 18: 00$ \\
\hline 調査方法 & \multicolumn{3}{|c|}{ ·歩道上より車道の状況をビデオ撮影 } & \multicolumn{2}{|c|}{ ·調査員によるナンバーフレート調査（録音方式） } \\
\hline 調査内容 & \multicolumn{3}{|c|}{ 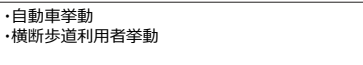 } & \multicolumn{2}{|c|}{$\begin{array}{l}\text { ·自動車ナンバープレート } \\
\text { (一更指定番号／車体番号（数字4桁）のみ） } \\
\text { ·車体色・差点流入出方向 }\end{array}$} \\
\hline \multirow[b]{2}{*}{ 調査箇所 } & 14箇所 & 3䇢所 & 11䇢所 & 8䇢所 & 像より取得) \\
\hline & 全地点 & $C, D, L$ & $\begin{array}{c}\mathrm{A}, \mathrm{B}, \mathrm{E}, \mathrm{F}, \mathrm{G}, \\
\mathrm{H}, \mathrm{I}, \mathrm{J}, \mathrm{K}, \mathrm{M}, \mathrm{N}\end{array}$ & \multicolumn{2}{|c|}{$\mathrm{A}, \mathrm{B}, \mathrm{C}, \mathrm{D}, \mathrm{E}, \mathrm{F}, \mathrm{G}, \mathrm{N}$} \\
\hline \multirow[b]{2}{*}{ 使用機材 } & & & $\begin{array}{l}\text { •ビデオカメラ } \\
\text { ·脚 }\end{array}$ & & $\cdot$ ICレコ-ダ- \\
\hline & & & & & \\
\hline
\end{tabular}

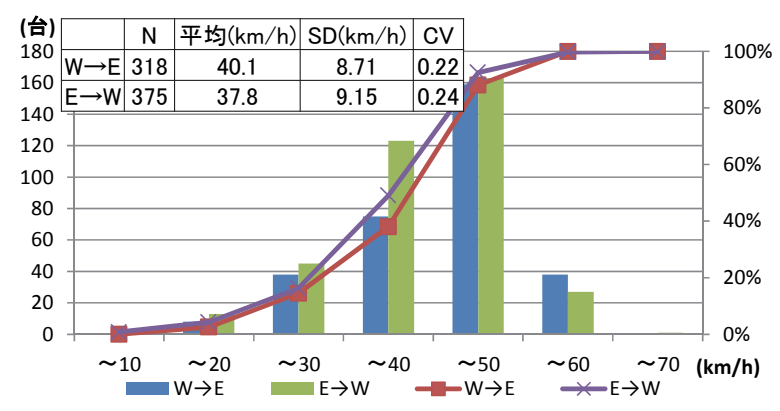

図-2Ｄ地点車両速度分布（7:30-9:00）

ート調査とビデオカメラ設置による観測調查を実施した を実施した。調査概要を表-1に示寸.

7:40-8:30の50分間のナンバープレート調查結果より, 植田東学区で国道 302 号と立体交差する C-D 地点間を通 過する自動車のうち, 東進交通で 31.8\%（N=201）, 西 進交通で 50.9\%（N=163）が通過交通であり，特に西向 きの交通は, 半数以上が地域外から学区に流入し通過し ていることが明らかになった. また, 観測調查より D地 点 (7:30-9:00) において, 横断歩道上を通過している時 間差と横断歩道幅から算出される自動車の走行速度を集 計したところ, 東進交通 $(\mathrm{W} \rightarrow \mathrm{E})$ は $30 \mathrm{~km} / \mathrm{h}$ 以上で走行 している車両が $86 \%, 40 \mathrm{~km} / \mathrm{h}$ 以上で走行している車両が $62 \%$, 西進交通 $(\mathrm{E} \rightarrow \mathrm{W})$ は, $30 \mathrm{~km} / \mathrm{h}$ 以上で走行してい る車両が $84 \%, 40 \mathrm{~km} / \mathrm{h}$ 以上で走行している車両が $51 \%$ で あった（図-2）。これより，多くの車両が歩行者致死率 の急上昇する $30 \mathrm{~km} / \mathrm{h}$ 以上で走行していることがわかる. なお，2014年秋に地域と連携して実施したアンケート 
調査（学区の町内会加入世帯を対象, 回収数 932 枚（回 収率 $50.6 \%$ ））でも高架下道路における安全対策の要望 が最多であることが示され，また，交通安全施策として は，交差点での安全対策が最も望まれ，ついで速度抑制 対策と歩行者の安全対策が地域住民に望まれていること がわかった.

\section{4. 道路狭さく設置社会実験および施工概要と道 路狭さくによる自動車の交通流動の変化}

\section{（1） 2015 年度の社会実験概要と交通流動の変化}

2014年度の交通実態調査により, 植田東学区の高架下 道路において多くの車両が $30 \mathrm{~km} / \mathrm{h}$ 以上で走行している ことや，生活道路内の通過交通が占める割合が高いこと が明らかになった. また，アンケート調査においても特 に国道 302 号との高架下道路において多くの安全対策要 望があることがわかった，そこで，植田東学区連絡協議 会, 名古屋市天白土木事務所, 天白警察署の連携協力の もと, 高架下道路の一部区間となる市道植田中央 197 号 線及び 239 号線（以下，社会実験実施区間）において, 主として車両の速度抑制と横断者の安全性向上を目的と した，道路狭さくによる社会実験（以降，2015年度社会 実験）が行われた. 実験の実施位置と道路狭さく概要を 図-3，図-4，図-5，表-2に示寸.

社会実験時においても，2014年度と同様の挙動調査を 実施し，その結果，路面表示とポールを有する単一の両 側道路狭さく単体で上流 30-40m, 下流 10-20m 区間の速 度抑制効果が見込めることや，カラーコーンによる簡易 な片側道路狭さくでも約 $5-10 \mathrm{~km} / \mathrm{h}$ の速度抑制効果がある ことが先行研究 ${ }^{22)}$ にりり明らかになった.

\section{（2） 2017 年度の道路狭さく施工概要と交通流動の変化}

2015年度の社会実験により，当該区間での道路狭さく 設置効果が確認されたことを受け，2017年 3 月に名古屋 市によって市道植田中央 197 号線及び 108 号線において 複数個の道路狭さくが整備された. 道路狭さくの概要を 表-3, 図-6, 図-7, 図-8 に示寸. 狭さくは, 路肩を確保 した上で，車道内に狭さくを設置した，なお，路肩と車 道を区分するデバイス等は設置されていない.

道路狭さくの施工後, 2015年度社会実験時と同様の調 査を実施した結果として，狭さく区間を含む $490 \mathrm{~m}$ 区間 の走行速度の変化を表-4に示寸. これより, 道路狭さく 未設置時と比較し， 7 時台における東進 $(\mathrm{C} \rightarrow \mathrm{D})$ 車両の 旅行速度は約 $2.2[\mathrm{~km} / \mathrm{h}]$ 低下（ヒ-3.573，有意差あり）, 西進 $(\mathrm{D} \rightarrow \mathrm{C})$ 車両の旅行速度は約 $2.6[\mathrm{~km} / \mathrm{h}]$ 低下 $(\mathrm{t}=4.197$ ，有意差あり）し，道路狭さくによる速度抑制 効果が確認された.

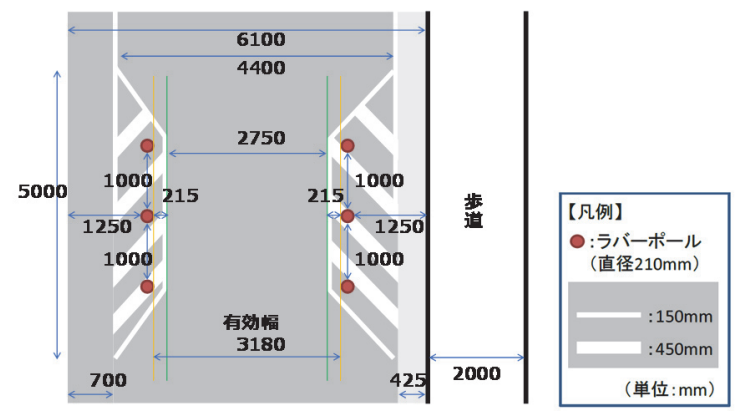

図-3 実験 1 の道路狭さく概要図

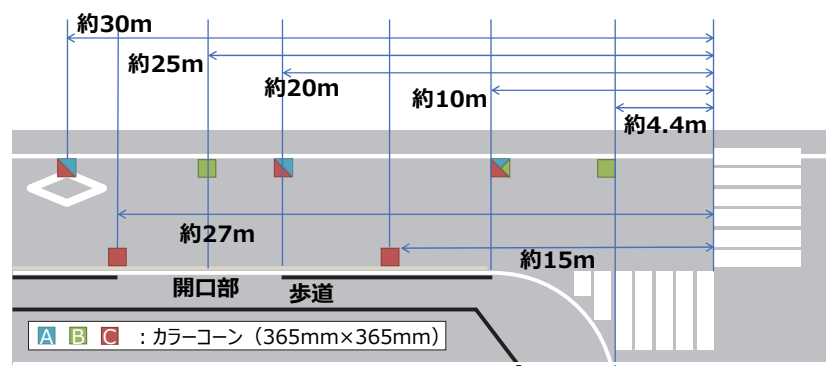

図-4 実験 2 の道路狭さく概要図 (西側)

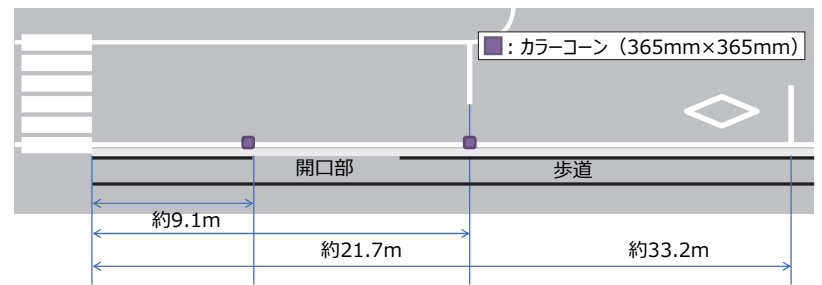

図-5 実験 2 の道路狭さく概要図（東側）

表-2 2015 年度社会実験概要

\begin{tabular}{|c|c|c|}
\hline & 実験1 & 実験2 \\
\hline $\begin{array}{l}\text { 実施 } \\
\text { 期間 }\end{array}$ & $\begin{array}{l}\text { 2015年9月29日～同年12月1日 } \\
\text { (2直所，常設) }\end{array}$ & $\begin{array}{l}\text { 2015年10月27日，28日 } \\
\text { (2日間，観測調査時のみ設置) }\end{array}$ \\
\hline 内容 & 狭さく（両側） & $\begin{array}{l}\text { カラーコーン設置による狭さく(片側，両側) } \\
\text { 西側 : 3パターン (A C) } \\
\text { 㝵側 : 1パターン (カラーコーン配置) }\end{array}$ \\
\hline
\end{tabular}

表-3 2017年度道路狭さく概要

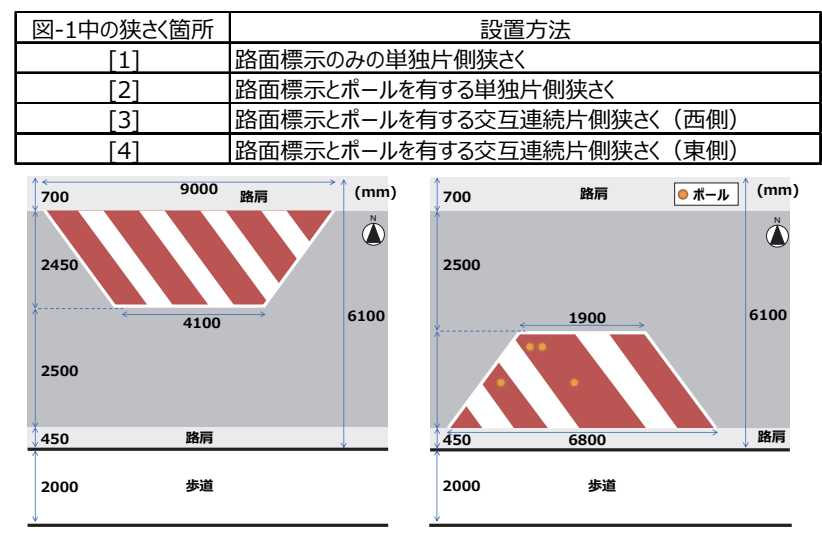

図-6 道路狭さく $[1]$ 概要困

図-7 道路狭さく[2]概要図

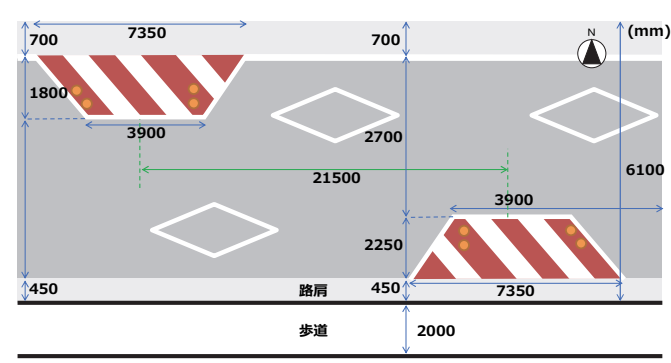

図-8 道路狭さく[3]（西側），[4]（東側）概要図 
(3) 路面標示のみの片側狭さくが車両走行特性に与え る影響分析

2017年度の狭さく施工においては, 図-1に示寸通り連 続して設置しており, 前項での分析結果の通り狭さく設 置区間全体では，速度低下が確認された。しかし，路面 標示のみの片側狭さくではポール等走行時の障害となる デバイスが設置されておらず，現地調査時も路面標示上 を通過する車両が確認された，そこで，本項では路面標 示のみ片側狭さく設置時の走行特性に与える影響を分析 する.

はじめに, 路面標示のみの片側狭さく設置による通行 車両の走行位置について集計する. 路面標示の通過定義 を図-9に，路面標示狭さく区間の走行位置集計結果を図 -10に示す.これより, 路面表示の狭さくが自車線側に ある東進車両のうち, 約 95\%が両輪で踏んで通過してい ることがわかる. 西進車両は, 約 $20 \%$ が片輪で踏んで 通過していることがわかる.

次に, 路面標示のみ狭さくの設置による速度抑制効果 を評価するため, 当該箇所の前後区間における平均走行 速度を比較する. 進行方向別路面標示のみ狭さく前後区 間の平均走行速度比較結果を表-5に示寸. これより, 東 進方向は路面標示のみ狭さく前後で平均走行速度が増加

（5\%有意）した．西進方向については，平均走行速度 が狭さく前後で約 $1[\mathrm{~km} / \mathrm{h}]$ 減少したが，有意な差は見ら れなかった. 以上より, 路面標示のみ狭さくの設置によ り設置箇所の走行位置の変化および速度抑制効果は確認 されなかった。

\section{5. 地域住民からみた道路狭さく設置に対する意 識変化に関する分析}

\section{(1) アンケート調査概要}

道路狭さくのない時点（以下，実験前（2014年度））, 社会実験中（以下，実験中（2015 年度）），道路狭さ く本施工後（以下，施工後（2017 年度））の 3 時点で, 愛知県名古屋市天白区植田東学区町内会加入世帯を対象 としたアンケート調査を実施した. なお各時点とも, 植 田東学区の各町内にてアンケート調査票と回収封筒を同 封して回覧し，紙面上にてアンケート調査を実施した. 各時点のアンケート調査概要を表-6から表-8 に示寸. 本 研究のアンケート調査では，世帯構成や個人属性のほか, 交通安全対策への意識・関心を把握するため, 交通安全 対策のために年間で支払っても構わない金額（支払意思 額）を尋ねることによって，交通安全対策の価值を金額 として評価する仮想市場評価法を適用した. 本研究で仮 想市場評価法を適用寸るにあたり，想定されるバイアス と調查時の対応方針を表-9 亿示寸，なお，仮想市場評価
表-4 2017年度道路狭さく設置前後の走行速度の変化

\begin{tabular}{|c|c|c|c|c|c|c|c|}
\hline & \multicolumn{3}{|c|}{ 道路狭さ〈設置前 } & \multicolumn{3}{|c|}{ 道路狭さ〈設置後 } & \multirow{2}{*}{ t値 } \\
\hline & 平均走行速度 & サンプル数 & 変動係数 & 平均走行速度 & サンブル数 & 変動係数 & \\
\hline 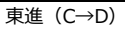 & 36.2 & 188 & 0.154 & 34.0 & 140 & 0.161 & $-3.573 * * *$ \\
\hline 西進 $(D \rightarrow C)$ & 33.4 & 175 & 0.168 & 30.8 & 153 & 0.180 & $-4.197 * * *$ \\
\hline
\end{tabular}

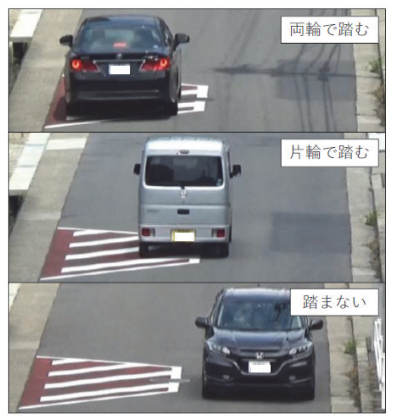

図-9＼cjkstart路面標示のみ狭さく区間の走行位置定義図

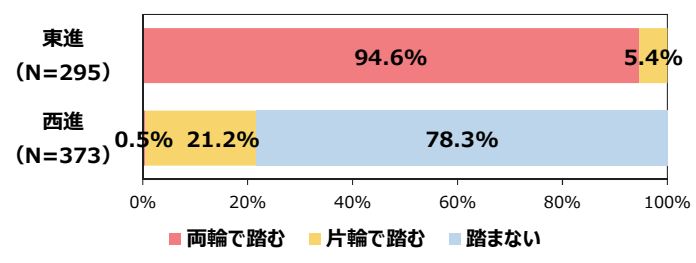

図-10 路面標示のみ狭さく区間の走行位置定義図（7-9 時)

表-5 路面標示のみ狭さく前後区間の平均走行速度比較

\begin{tabular}{|c|c|c|c|c|c|}
\hline & 狭さ〈通過直前 & (約19m) & 狭さ〈通過直後 & （約17m） & \multirow[b]{2}{*}{ t値 } \\
\hline & $\begin{array}{c}\text { 平均走行 } \\
\text { 速度 }[\mathrm{km} / \mathrm{h}]\end{array}$ & 変動係数 & $\begin{array}{c}\text { 平均走行 } \\
\text { 速度 }[\mathrm{km} / \mathrm{h}]\end{array}$ & 変動係数 & \\
\hline $\begin{array}{c}\text { 東進 } \\
(\mathrm{N}=81)\end{array}$ & 37.5 & 0.099 & 40.1 & 0.105 & $-1.983^{* *}$ \\
\hline $\begin{array}{c}\text { 西進 } \\
(\mathrm{N}=101)\end{array}$ & 39.1 & 0.072 & 38.1 & 0.069 & 1.080 \\
\hline
\end{tabular}

表-6 実験前（2014年度）の調查概要

\begin{tabular}{|c|c|c|}
\hline \multicolumn{2}{|r|}{ 実施時期 } & 2014年8月 \\
\hline & 配布数 & 1,843 枚 \\
\hline & 回収数 & 932枚（回収率 : 50.6\%） \\
\hline \multirow{2}{*}{ 主 } & 世帯構成 & $\begin{array}{l}\text { ·所在地区 ·世帯人数 } \cdot \text { 自家用車保有台数 } \\
\text {.中学生以下の子供の有無 }\end{array}$ \\
\hline & 個人属性 & ·年齢 $\quad$ ·居住年数 $\quad$ ·性別 \\
\hline 調 & 自家用車の利用状況 & $\begin{array}{l}\cdot \text { 利用頻度 } \cdot \text { ·利用目的 } \\
\cdot \text { 平日朝 }(7: 30 \sim 9: 00) \text { の利用頻度 } \\
\cdot \text { ·平日夕 }(16: 30 \sim 18: 00) \text { の利用頻度 }\end{array}$ \\
\hline 垻 & 交通安全対策への意識 & ·仮想市場評価法 (CVM) \\
\hline & $\begin{array}{c}\text { 学区の速度抑制 } \\
\text { 対策について }\end{array}$ & ·狭さくの対策実施の賛否 \\
\hline
\end{tabular}

表-7 実験中（2015 年度）の調査概要

\begin{tabular}{|c|c|c|c|}
\hline & 実施時期 & 2015年10月 & \\
\hline & 配布数 & 1,863枚 & \\
\hline & 回収数 & 1,053枚（回収率 : 56.5\%） & \\
\hline & 世帯構成 & $\begin{array}{l}\text { ·所在地区 ·世帯人数 ·自家用 } \\
\text { ·中学生以下の子供の有無 }\end{array}$ & 車保有台数 \\
\hline & 個人属性 & ·年齢 ·居住年数 ·性別 & \\
\hline & 自家用車の利用状況 & $\begin{array}{l}\cdot \cdot \text { 利用頻度 ·利用目的 } \\
\cdot \text { 平日朝 }(7: 30 \sim 90) \text { の利月 } \\
\cdot \text { ·平日夕 }(16: 30 \sim 18: 00) \text { の }\end{array}$ & 頻度 \\
\hline & & ·社会実験開始前の実験箇所の柇 & 用頻度 \\
\hline & $\begin{array}{c}\text { 狭さ〈設置区間の } \\
\text { 利用状況およひ評価 }\end{array}$ & $\begin{array}{l}\text { ·社会実験の認知度 } \\
\text { ·社会実験箇所の速度抑制意識 } \\
\text { ·社会実験箇所の宔性の変化 } \\
\text { ·社会実験箇所の使いやすさ }\end{array}$ & 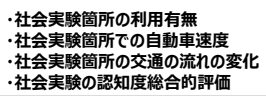 \\
\hline & 交通安全対策への意識 & ·仮想市場評価法 (CVM) & \\
\hline
\end{tabular}

表-8 施工後（2017年度）の調查概要

\begin{tabular}{|c|c|c|c|}
\hline \multicolumn{2}{|r|}{ 実施時期 } & \multicolumn{2}{|l|}{ 2017年7月 } \\
\hline \multirow{2}{*}{\multicolumn{2}{|c|}{$\begin{array}{l}\text { 配布数 } \\
\text { 回収数 }\end{array}$}} & \multicolumn{2}{|l|}{1,884 枚 } \\
\hline & & \multicolumn{2}{|l|}{ 946枚（回収率：50.2\%） } \\
\hline \multirow{6}{*}{ 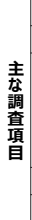 } & 世帯構成 & \multicolumn{2}{|c|}{-所在地区 ·世帯人数 ·自家用車保有台数 } \\
\hline & 個人属性 & \multicolumn{2}{|l|}{ ·年齡 ·居住年数 ·性別 } \\
\hline & 独さく摆反聞の & \multicolumn{2}{|c|}{ 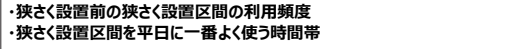 } \\
\hline & 利用状湻およひ評価 & 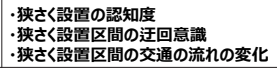 & $\begin{array}{l}\text { ·狭さ人設置区間での速度抑制意識 } \\
\text { 狭さく設置区間の安全性の変化 }\end{array}$ \\
\hline & 交通安全対策への意識 & \multicolumn{2}{|l|}{ ·仮想市場評価法（CVM） } \\
\hline & 学区の速度抑制対策について & \multicolumn{2}{|l|}{.狭さくの効果 } \\
\hline
\end{tabular}


法での聞き取りの際には，支払いカード方式で 11 の選 択肢（0 円，100 円，200 円，300 円，500 円，1000 円， 1500 円，2000 円，3000 円，5000 円，10000 円以上（具体 的金額））を尋ね，併せて，この負担をすることにより 家計で使用できる金額が減る注意事項も明示した。なお, 当学区で進める施策が確定していなかった実験前（2014 年度）は生活道路の安全施策全般に対寸る支払意思額, 施策が確定した後の実験中（2015 年度），施工後（2017 年度）は道路狭さくに限定した支払意思額を尋ねている。 また, 回答者属性の一例として施工後（2017年度）時の 結果を図-11に示寸.

アンケート調査票の配布数は, 各時点とも同程度であ り，回收率は多少異なるものの，50\%以上を確保できて いる. また図-11 に示寸回答者属性の結果から幅広い年 代, 利用属性が得られているといえる. なお, 他の時点 においても回答者属性に違いは見られなかった。 以降, アンケート調査結果を用いて, 時点別の道路狭さく設置 効果の評価の変化を分析する.

\section{(2) 交通安全施策の効果に対する意識分析}

実験中（2015年度）調査，施工後（2017年度）調査で 得られた結果のうち, 道路狭さく区間を自動車で通行し た回答者を対象に，道路狭さく設置の有無による速度抑 制意識や円滑性・安全性の変化を分析した．速度抑制意 識变化に関する結果を図-12, 円滑性変化に関する分析 結果を図-13, 安全性変化に関寸る分析結果を図-14に示 す. なお, 調査時は, 道路狭さく設置前の時点と比較し た変化の有無を問うている，また各設問に対し，未回答 は除いて集計した。

速度抑制意識の変化については, 速度低下の動機が異 なる $\left(\chi^{2}=46.01, \mathrm{p}=0.00\right)$ ものの, ほとんどの回答者が道 路狭さく設置区間で速度を落とそうと思ったとの結果で ある，道路狭さく設置により幅員が狭くなり，対向車が 存在する場合にすれ違うための幅員がないため, 速度を 落とさざるを得ない状況が発生するためと考えられる.

円滑性の変化については, 各時点とも回答者の約 6 割 が円滑性が低下したと実感した．また，円滑性について は時点により回答分布の違いは確認されなかった $\left(\chi^{2}=\right.$ $5.85, \mathrm{p}=0.12)$.

安全性の変化については，これより半数程度以上が狭 さく設置により安全性が高まったと回答する一方で 1 割 程度が安全性が低下したと評価していることがわかる。

また，時点による回答分布の違いは確認されなかった $\left(\chi^{2}=17.38, p=0.07\right)$.

以上の結果より, 自動車利用者に対し, 自動車の減速 を促すという道路狭さく設置の狙いに合致した意識の変 化が確認された.
表-9 本研究における想定されるバイアスと調查時対応方針
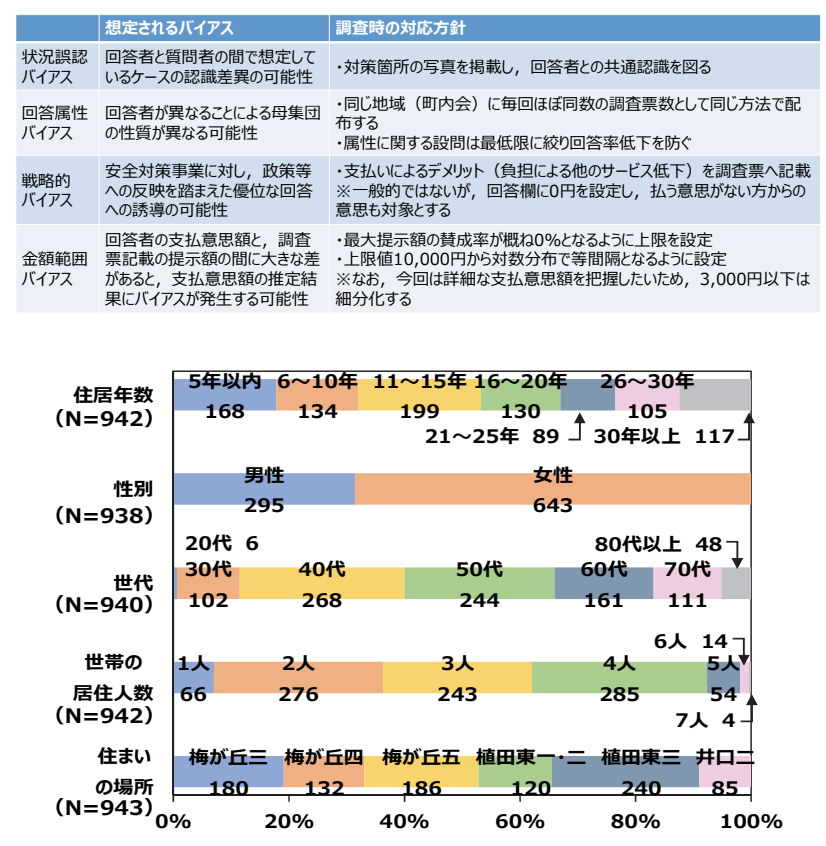

図-11 アンケートの回答者属性（施工後（2017年度））

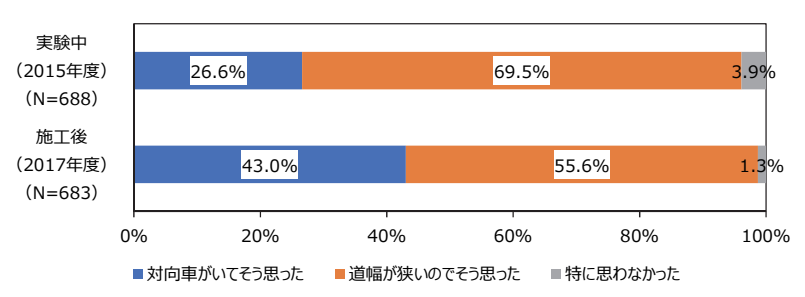

図-12 速度抑制意識に関する調查結果

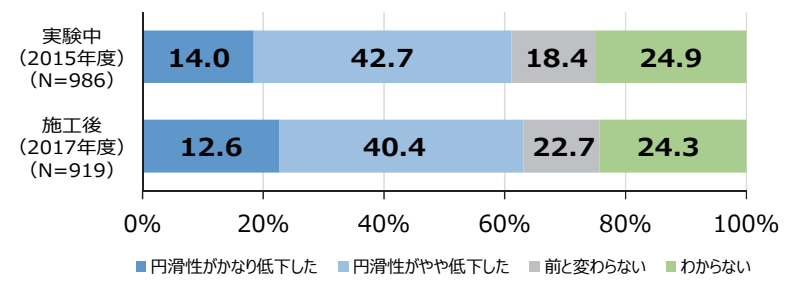

図-13 円滑性の変化に関する評価結果

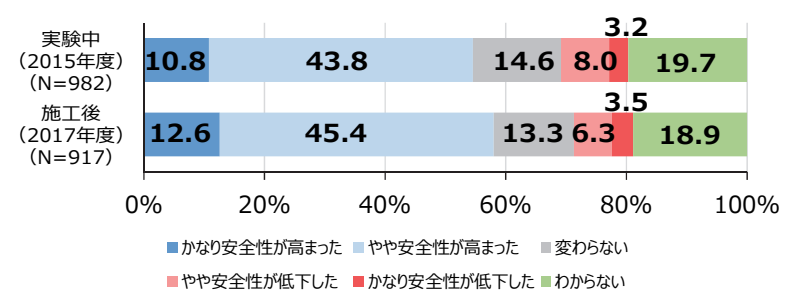

図-14 安全性の変化に関する評価結果

\section{6. 仮想市場評価法を用いた住民の道路狭さく対 策評価への影響分析}

前章までの分析により，道路狭さく対策は，自動車利 用者に対し，減速を促していることがわかり，住民もそ の効果を実感していることがわかった，本章では，仮想 
市場評価法で得られた支払意思の有無に対し，どのよう な属性および利用実態が影響するのかを把握する.

\section{（1）支払意思額に関する基本集計結果}

時点毎の回答金額の分布特性および平均金額を図-15 にまとめる．これより，時間経過とともに平均值は低下 傾向にあるが，実験前とそれ以降では 1000 円以上の回 答者割合が大きく減少していることが影響しているとい える。これは実験前（2014年度）は交通安全全般につい ての支払意思額であること，また，同エリアで生活道路 安全対策が実施されていない時点の調查であるため, 効 果を高く見積もって評価した結果を反映していると推察 される.また，狭さくが設置されている実験中（2015年 度）と施工後（2017年度）では，支払意思額の分布につ いても有意な差が生じており $\left(\chi^{2}=48.81, \mathrm{p}<0.01\right)$ ，平 均值も減少していることから，狭さく設置から時間が経 過するにつれて，平均支払意思額が減少寸る結果となっ た. 円滑性の評価（図-13），安全性の評価（図-14）で は有意な差が見られなかったことを考慮すると, 狭さく に対する効果は同程度実感しているものの，時間が経過 するにつれて，狭さくに対する関心度が低下寸ることが 考えられる.

図-1に示すエリアごとに集計，算出した平均支払意思 額を時点別に整理した結果を図-16に示寸.

これより，どのエリアも実験前の金額が最も高く，時 間経過とともに金額が低下寸る傾向にある。実験中

（2015 年度）では植田東一・二丁目が最も高い值で, 施工後（2017年度）では梅が丘四丁目が最も高い值を示 すなど，時点により評価結果が異なる傾向にある.

なお，先述の通り実験前（2014年度）調査では, 交通 安全施設全般についての支払意思額を問うており，異な る調查時期間の比較検定は好ましくないため, 以降の統 計的検定においては，同時期調查内での統計的検定を実 施・考察する.

\section{（2）居住エリア別支払意思表示住民割合の推移}

道路狭さく対策に対し, 支払意思を示寸住民の割合が, 時間経過とともにどのように推移するかを把握するため, 植田東学区を表-10 に示寸 2 つ居住エリアに分割して 集計を行う。なお，居住エリアの分割にあたり，今回道 路狭さくを実施した箇所は植田東学区の南部に位置する こと，また，道路狭さく区間を通学路および自動車利用 すると想定される居住エリアを南部，その他の居住エリ アを北部と定義した．支払意思割合の推移を図-17 に示 す.

その結果，実験前（2014年度）と，実験中（2015年度） 調査結果では，エリア北部，南部で割合に対し有意差は 確認されない（実験前（2014 年度） : $t=0.76, p=0.45$ ，実

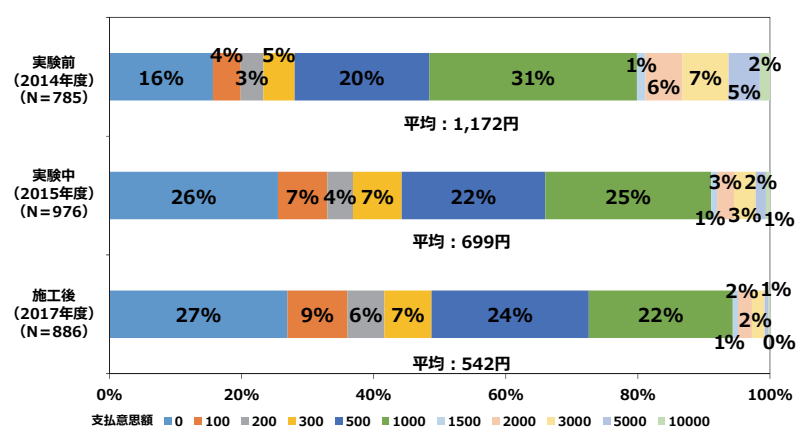

図-15 支払意思額の時点別の回答傾向

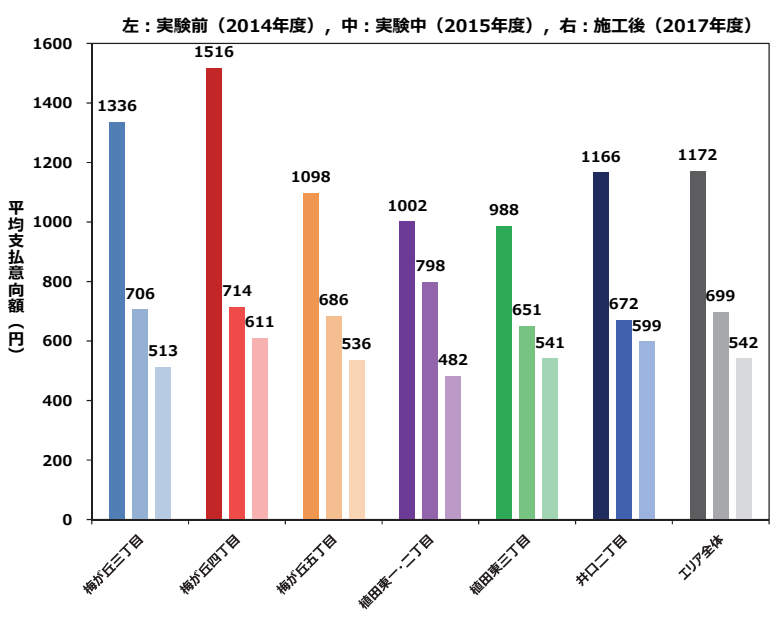

図-16 平均支払意向額のエリア別，時点別の特性

表-10 エリア定義
\begin{tabular}{|c|c|}
\hline エリア名 & 町名 \\
\hline エリア北部 & 梅が丘三丁目，梅が丘五丁目，植田東一·二丁目 \\
\hline エリア南部 & 梅が丘四丁目，植田東三丁目，井口二丁目 \\
\hline
\end{tabular}

支払意思あり割合 （）は設問回答数

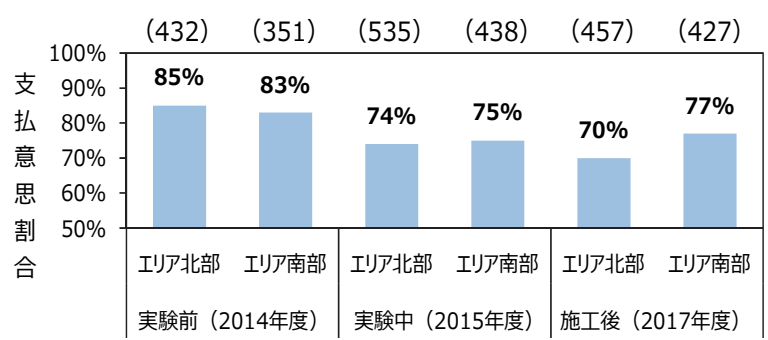

図-17 支払意思割合の推移

験中（2015 年度） : $t=0.54, p=0.59 ）$ が，道路狭さく設 置から時間が経過した施工後（2017年度）調査結果では, エリア南部のほうが支払意思を示寸住民の割合が高、傾 向となった $(t=2.28, p=0.02)$ 。これは，道路狭さく設 置前や経験が浅い社会実験中では，道路狭さくを設置す ることで，学区の交通安全施策に貢献するというイメー ジをエリア問わず持っているため差が生じないが，時間 が経過するにつれて，エリア南部のほうが道路狭さく設 置の恩恵を受けやすく, また効果を実感しやすいため, 道路狭さくへの支払意思を示寸傾向にあると推察される. 


\section{(3) 判別分析による道路狭さくの評価への影響分析}

住民の交通安全対策や道路狭さくへの支払意思へ与え る要因や, 道路狭さくの設置前後における意識の変化を 把握するため, 支払意思の有無を目的変数, 各回答者の 世帯属性, 個人属性や道路狭さくへの賛否, 効果の実感 有無，さらには道路狭さく区間利用時の意識変化を説明 変数とした判別分析を行う. 判別分析の説明変数候補を 表-10 に，判別分析結果を表-11 に示す．なお，実験前 （2014 年度）調查結果では，有意水準 5\%では有意な結 果が得られなかったため，傾向把握のために有意水準を 10\%とした結果を採用している.

判別分析の結果より，実験前（2014年度）調査時では, 「道路狭さく対策に賛成」が正となった．社会実験前で は道路狭さく対策の概要（対策の目的や整備形態）のみ 情報提供しているが，学区の通学路の安全性向上に寄与 するため支払意思を示していると推察される.また，

「中学生以下の子供がいる家庭」が正の係数であり，今 回の道路狭さく区間が通学路に指定されている区間であ るため, 通学路の安全性向上に寄与寸るため支払意思を 示していると推察される.

実験中（2015年度）調査時では，社会実験前と同様， 「中学生以下の子供がいる家庭」が正の係数となった. また，道路狭さく区間を車で利用すると支払意思を示す 傾向にあり，実際に道路狭さく区間を利用寸ることで, 道路狭さく対策について関心度が増加すると推察される. また，「植田東学区の北部に居住」，「2 人以下の世帯」 が負の係数となった. これは, 道路狭さく区間が植田東 学区の南部に位置することや子供がいないため通学路と しての利用がない等，道路狭さくの効果を実感できない 方には関心を得られないためと推察される.

施工後（2017年度）調查時では，「道路狭さく対策は 効果があると認識」，「道路狭さく対策により安全性向 上したと認識」が正の係数となった. これより，実際に 道路狭さく区間を利用し，詨策の効果や安全性向上を実 感した方は支払意思を示傾向にあり，道路狭さくによ る効果の実感が評価に直接影響していると考えられる.

「道路狭さくにより経路の変更を検討したことがある」 が負の係数となった. この結果より, 道路狭さくにより 自動車での利便性が低下し, 道路狭さく対策の評価が下 がると考えられる.

以上より, 道路狭さく設置前では, 中学生以下の子供 の有無や道路狭さく対策のイメージが支払意思へ影響し ていたが，道路狭さく設置して時間が経つにつれて，道 路狭さく効果の実感や恩恵の有無が支払意思へ影響する ようになったといえる.
表-11 説明変数候補一覧

\begin{tabular}{|c|c|c|c|c|}
\hline 説明変数 & 内容 & \begin{tabular}{|c|} 
2014年度 \\
調查時 \\
\end{tabular} & \begin{tabular}{|c|} 
2015年度 \\
調查時 \\
\end{tabular} & \begin{tabular}{|c|c|c|c|} 
2017年度 \\
調查時 \\
\end{tabular} \\
\hline \begin{tabular}{|l|} 
植田東学区の \\
北部に居住
\end{tabular} & $\begin{array}{l}\text { 回答者が海が乓三丁目，梅が丘五目，植田東一. } \\
\text { 目目であれば1，そうれなければ0 }\end{array}$ & 0 & 0 & 0 \\
\hline \begin{tabular}{|l|} 
植田東学区の \\
南部に居住
\end{tabular} & 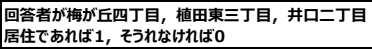 & 0 & 0 & 0 \\
\hline 自家用車保有多ミー & $\begin{array}{l}\text { 回答者が自家用車を保有していれば1， } \\
\text { そうれなければ0 }\end{array}$ & 0 & 0 & \\
\hline $\begin{array}{l}\text { 中学生以下の } \\
\text { 子供がいるタミ- }\end{array}$ & $\begin{array}{l}\text { 回答者の世帯に中学生以下の子供がいる場合1， } \\
\text { そうでなげ0 }\end{array}$ & 0 & 0 & \\
\hline 2人以下の世帯舛ー & $\begin{array}{l}\text { 回答者の世帯が2人以下で構成されていれば 1， } \\
\text { そうでなげれ゙ }\end{array}$ & 0 & 0 & 0 \\
\hline 3人以上の世帯舛- & $\begin{array}{l}\text { 回答者の世帯が3人以上で構成されていれば 1， } \\
\text { そうでなげれ゙ }\end{array}$ & 0 & 0 & 0 \\
\hline $\begin{array}{l}\text { 狭さく区間を車で } \\
\text { 利用したタミー }\end{array}$ & $\begin{array}{l}\text { 回答者が狭さく区間を自動車で利用していれば 1， } \\
\text { そうれければ0 }\end{array}$ & 0 & 0 & 0 \\
\hline \begin{tabular}{|l} 
狭さく区間利用時 \\
速度抑制意欲ありタシミ-
\end{tabular} & \begin{tabular}{|l} 
回䉀者が狭さく区間利用時に \\
速度を落とそうとしこことがあれば1，そうれなけれれば0
\end{tabular} & & & 0 \\
\hline $\begin{array}{l}\text { 狭さく設置により } \\
\text { 経路変更検討したタタミ- }\end{array}$ & 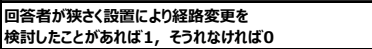 & & & 0 \\
\hline 狭さく対策に酚成多ミー & $\begin{array}{l}\text { 回答者が狭さく設置に贊成であれば1， } \\
\text { そうれなければ0 }\end{array}$ & 0 & 0 & \\
\hline $\begin{array}{l}\text { 狭さく対策は効果が } \\
\text { あると認識㚈ミ- }\end{array}$ & $\begin{array}{l}\text { 回答者が狭さく設置は効果があると認識した51， } \\
\text { そうれなれれは0 }\end{array}$ & & & 0 \\
\hline $\begin{array}{l}\text { 狭さく対策により } \\
\text { 安全性が向上したタミ- }\end{array}$ & $\begin{array}{l}\text { 回答者が狭さく設置により安全性が } \\
\text { 向上したと实感した51，そうれなければ0 }\end{array}$ & & 0 & 0 \\
\hline
\end{tabular}

表-12 判別分析結果

\begin{tabular}{|c|c|c|c|c|c|c|c|}
\hline & \multicolumn{2}{|c|}{$\begin{array}{c}\text { 実験前 } \\
\text { (2014年度) }\end{array}$} & \multicolumn{2}{|c|}{$\begin{array}{c}\text { 実験中 } \\
\text { (2015年度) }\end{array}$} & \multicolumn{2}{|c|}{$\begin{array}{c}\text { 施工後 } \\
\text { (2017年度) }\end{array}$} \\
\hline & & 標準化係数 & F値 & 標準化係数 & F値 & 標準化係数 & F値 \\
\hline \multicolumn{2}{|c|}{ 植田東学区の北部に居住 } & 0.538 & $3.566 * * *$ & -0.691 & $41.362 *$ & & \\
\hline \multicolumn{2}{|c|}{ 中学生以下の子供がいる世帯 } & 0.650 & $5.186 * *$ & 0.833 & $61.356 *$ & & \\
\hline \multicolumn{2}{|c|}{ 2人以下の世帯 } & & & -0.265 & 6.017* & & \\
\hline \multicolumn{2}{|c|}{ 狭さ〈対策に賛成 } & 0.512 & $3.206 * * *$ & & & & \\
\hline \multicolumn{2}{|c|}{ 狭さく区間を車で利用した } & & & 0.215 & $3.918 * *$ & & \\
\hline \multicolumn{2}{|c|}{ 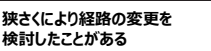 } & & & & & -0.235 & $3.882 * *$ \\
\hline \multicolumn{2}{|c|}{ 狭さく対策は効果があると認識 } & & & & & 0.460 & $11.372 *$ \\
\hline \multicolumn{2}{|c|}{ 狭さ〈対管により } & & & & & 0.648 & $22.735 *$ \\
\hline \multirow{2}{*}{ 重心 } & 支払意思有 & \multicolumn{6}{|c|}{ 正 } \\
\hline & 支払意思無 & \multicolumn{6}{|c|}{ 負 } \\
\hline \multicolumn{2}{|c|}{ 的中率 $[\%]$} & \multicolumn{2}{|c|}{59.10} & \multicolumn{2}{|c|}{87.67} & \multicolumn{2}{|c|}{63.63} \\
\hline \multicolumn{2}{|c|}{ 標本数 } & \multicolumn{2}{|c|}{753} & \multicolumn{2}{|c|}{649} & \multicolumn{2}{|c|}{943} \\
\hline \multicolumn{2}{|l|}{ p値 } & \multicolumn{2}{|c|}{$<0.01$} & \multicolumn{2}{|c|}{$<0.01$} & \multicolumn{2}{|c|}{$<0.01$} \\
\hline
\end{tabular}

(*: 1\%有意， $* * ： 5 \%$ 有意，*** : 10\%有意)

\section{7. おわりに}

本研究では, 愛知県名古屋市天白区植田東学区を対象 として道路狭さくの設置前後および施工前後にて，自動 車の旅行速度の変化を把握した. その結果, 道路狭さく 設置により旅行速度が低下し，道路狭さくの目的である 速度抑制効果が発現していることがわかった，また，設 置前後における自動車利用者の意識の変化をアンケート 調査にて把握した。 その結果, 道路狭さく設置により 9 割近い人が車両の速度を低下させる意識をする一方で, 6 割の人が交通流の円滑性低下を感じ, 総合評価として 3割の人が良くないとしたことを明らかにした.

さらに，仮想市場評価法を用いた住民の道路狭さくへ の支払意思を複数時点で調查し, 道路狭さく設置前, 設 置地直後, 時間経過後での支払意思に対する住民の意識 の変化を分析した，その結果，道路狭さくの設置前では 中学生以下の子どもの有無や利用の有無が支払意思へ影 響していたが，道路狭さく設置から経過後では，設置に よる道路狭さく区間の利便性の低下や道路狭さく効果の 実感の有無が影響することがわかり，地域住民の道路狭 さくに対する意識の変化が確認された. 
なお，今回の道路狭さく設置では設置位置制約もあり， 連続狭さくは，左右同一形状（張り出し幅を同一）にし たことで優先・非優先を明確にしなかったことから，自 動車利用者から通過時に対向車がいると危険であるとい う意見も確認された．連続狭さくの設置においては，狭 さくの大きさを進行方向ごとに変更する等, 双方向から 車両が接近した際の優先権の明確化が必要である。また， 図-6に示す路面標示のみの道路狭さくを設置した理由は, 沿道住民の駐車場乗入の利便性へ配慮したことによる設 置パターンであったが，当該パターンでは，路面標示上 を通過する車両が存在し，また対策前後で速度低下の結 果が得られなかった.今後は今回の知見も踏まえ, 駐車 場の乗り入れ部付近等，沿道の住宅立地事情などの制約 を考慮し, 連続狭さくの設置が困難な箇所では片側狭さ く（ポールあり）の設置する等，より現実的かつ効果的 なデバイス設置方法を検討していく必要があるといえる. 今後は，交通安全施策のコストについても整理し，デ バイス設置効果との比較による検証を行う。

謝辞：本研究は，科研費（基盤研究（C）16K06536）の 助成を受けたものである，また，本研究を進めるにあた り，植田東学区連絡協議会交通部会の関係の方々の多大 なご協力を得た. ここに記して謝意を表する.

\section{参考文献}

1) 警察庁交通局 : 平成 29 年中の交通事故の発生状況, https://www.npa.go.jp/publications/statistics/koutsuu/ H29zennjiko.pdf, p.1

2) 国土交通省道路局 : 安全で人優先の道路空間の形成 について, http://www.mlit.go.jp/road/ir/kihon/21/4.pdf, p.11

3) 名古屋市市民経済局：名古屋市内の交通事故（平成 24～25 年中)

4) 内閣府政策統括官（共生社会政策担当）付交通安全 対策担当：OECD等における速度管理に係る施策等, http://www8.cao.go.jp/koutu/taisaku/max-speed/k_1/pdf/s5. pdf, pp.2-3

5) 埼玉県警察：埼玉県警察速度管理指針， http://www. police.pref.saitama.lg.jp/kenke/kesatsusho/tokorozawa/ documents/kanri.pdf

6) 警察庁交通局：速度規制の見直し状況と課題, https://www.npa.go.jp/koutsuu/kikaku/regulation_wg/kisei_wg/01/siryoul.pdf

7) 生活道路におけるゾーン対策推進調查研究検討委員 会：生活道路におけるゾーン対策推進調查研究報告 書, https://www.npa.go.jp/koutsuu/kisei/houkokusyo.pdf

8) 鬼塚大輔, 大橋幸子, 稲野茂：ハンプおよびシケイ ンの効果的な設置位置と間隔に関する研究, 土木計 画学研究・講演集, Vol. 51, CD-ROM, 2015.

9) 大橋幸子, 鬼塚大輔, 稲野茂: 生活道路への流入車 両に対する幹線道路のスムース歩道・交差点道路狭 さくの効果, 土木計画学研究・講演集, Vol. 51, CDROM, 2015.

10) 伊藤克広, 本田肇, 高橋治, 金子正洋 : 生活道路に おける道路狭さくの速度抑制効果に関する研究，土 木計画学研究・講演集, Vol. 40, CD-ROM, 2010.

11) 国土交通省：生活道路における物理的デバイス等検 討委員会, http://www.mlit.go.jp/road/ir/ir-council/life_ $\mathrm{road} /$ index.html

12）堀川智貴，堀将誌，鈴木弘司：生活道路における道 路狭さくの設置効果に関する実証的分析，第 36 回交 通工学研究会論文集, 8ページ, 2016.

(Received February 22, 2019)

(Accepted August 26, 2019)

\section{ANALYSIS OF THE EFFECT OF CHOKER AT RESIDENTIAL ROAD AND CHANGE IN INHABITANTS' CONSCIOUSNESS FOR TRAFFIC SAFETY COUNTERMEASURE BY FIELD SURVEY}

\section{Koji SUZUKI and Hiroki ITO}

This study clarified the traffic issues at residential roads in an elementary school district, Nagoya city by observation and questionnaire. Discussing the results of these surveys with inhabitants of the district, we planned to conduct social experiment for reducing vehicle speed by a choker installation on basic section and then several chokers as full-scale countermeasure were installed by road management authority in the same road section. In this study, we examined the effect of these countermeasures from both traffic flow and inhabitants consciousness by temporal analyses. As the results of these countermeasures, the reduction of spot speed was confirmed for social experiment and the reduction of travel speed was also revealed for several chokers of full-scale countermeasure. Based on the analysis of willingness to pay (WTP) of inhabitants for these safety countermeasures which were measured by CVM, it is found that the family with/without children or the driving experience of the choker section have an affect on the WTP. In addition, it is also revealed the change in consciousness for the installation of chokers with time. That is, both the evaluation for convenience of this section and the real sense of the effect by the choker have impact on their WTP. 